Research Paper

\title{
Interferon-Gamma-Induced Nitric Oxide Inhibits the Proliferation of Mu- rine Renal Cell Carcinoma Cells
}

\author{
David J. Tate Jr. ${ }^{1}$, John R. Patterson ${ }^{1}$, Cruz Velasco-Gonzalez ${ }^{2}$, Emily N. Carroll ${ }^{3}$, Janie Trinh ${ }^{1}$, Daniel \\ Edwards ${ }^{1}$, Ashok Aiyar ${ }^{1,4}$, Beatriz Finkel-Jimenez ${ }^{1}$, and Arnold H. Zea ${ }^{1,4,5, \bowtie}$
}

1. Stanley S. Scott Cancer Center, LSUHSC, New Orleans, LA, 70112;

2. Department of Public Health, LSUHSC, New Orleans, LA, 70112;

3. Ohio State University-College of Medicine, LSUHSC, New Orleans, LA, 70112;

4. Microbiology Immunology and Parasitology, LSUHSC, New Orleans, LA, 70112;

5. Section of Pulmonary and Critical Care Medicine, LSUHSC, New Orleans, LA, 70112.

$\triangle$ Corresponding author: Arnold H. Zea, PhD. Stanley S. Scott Cancer Center, Louisiana State University HSC, 533 Bolivar St, CSRB Room: 453, New Orleans, LA 70112, USA. Phone: (504) 599-0906, Fax: (504) 568-6888, E-mail: azea@lsuhsc.edu.

(ㅇ Ivyspring International Publisher. This is an open-access article distributed under the terms of the Creative Commons License (http://creativecommons.org/ licenses/by-nc-nd/3.0/). Reproduction is permitted for personal, noncommercial use, provided that the article is in whole, unmodified, and properly cited.

Received: 2012.06.04; Accepted: 2012.08.26; Published: 2012.09.06

\begin{abstract}
Renal cell carcinoma (RCC) remains one of the most resistant tumors to systemic chemotherapy, radiotherapy, and immunotherapy. Despite great progress in understanding the basic biology of RCC, the rate of responses in animal models and clinical trials using interferons (IFNs) has not improved significantly. It is likely that the lack of responses can be due to the tumor's ability to develop tumor escape strategies. Currently, the use of targeted therapies has improved the clinical outcomes of patients with RCC and is associated with an increase of ThI-cytokine responses (IFN $\gamma$ ), indicating the importance of IFN $\gamma$ in inhibiting tumor proliferation. Thus, the present study was designed to investigate a new mechanism by which IFN $\gamma$ mediates direct anti-proliferative effects against murine renal cell carcinoma cell lines. When cultured RCC cell lines were exposed to murine recombinant IFN $\gamma$, a dose dependent growth inhibition in CL-2 and CL-19 cells was observed; this effect was not observed in Renca cells. Growth inhibition in CL-2 and CL-19 cell lines was associated with the intracellular induction of nitric oxide synthase (iNOS) protein, resulting in a sustained elevation of nitric oxide (NO) and citrulline, and a decrease in arginase activity. The inhibition of cell proliferation appears to be due to an arrest in the cell cycle. The results indicate that in certain RCC cell lines, IFN $\gamma$ modulates L-arginine metabolism by shifting from arginase to iNOS activity, thereby developing a potent inhibitory mechanism to encumber tumor cell proliferation and survival. Elucidating the cellular events triggered by IFN $\gamma$ in murine RCC cell lines will permit anti-tumor effects to be exploited in the development of new combination therapies that interfere with L-arginine metabolism to effectively combat RCC in patients.
\end{abstract}

Key words: nitric oxide, Interferon-gamma, nitric oxide synthase, renal cell carcinoma, arginase 2, polyamines, L-arginine, cell proliferation.

\section{INTRODUCTION}

Renal cell carcinoma (RCC) accounts for $5 \%$ of all cancers, leading to an estimate of 13,120 mortalities each year in the United States (1). RCC remains one of the most resistant tumors to immunotherapy, chem- otherapy, and radiotherapy (2). The overall survival for all RCC patients has not appreciably improved during the last 25 years, indicating the need for more effective ways to treat this disease. Immunotherapy 
with interferon alpha (IFN $\alpha$ and/or interleukin-2 (IL-2)) has been used as a first-line therapy to treat RCC, but the documented clinical response rate in patients is only $10-20 \%$, with a median survival of approximately 12 months (3-5). In recent years, the advent of targeted therapies for metastatic RCC has grown substantially (6-9); however, these therapies do not produce complete responses and have several adverse effects, and their mechanisms of action are poorly understood.

There is a complex relationship between immunity, tumorigenesis, and the metabolism of L-arginine $(10 ; 11)$ that can be highly relevant to RCC. Recent studies have demonstrated convincingly that the enzymes arginase 1 (ARG1), arginase 2 (ARG2), and inducible nitric oxide synthase (iNOS) play a crucial role in tumor biology (12-14). ARG1 and ARG2 are collectively referred to as ARG in this manuscript because their activities are similar. L-arginine is metabolized by ARG, producing L-ornithine, as substrate for ornithine decarboxylase (ODC) to synthesize polyamines that are essential for cell growth. In contrast, iNOS metabolizes L-arginine to produce nitric oxide (NO) that kills tumor cells by mechanisms that are partially understood (15-17). Since ARG and iNOS compete for L-arginine, this amino acid is a crucial component whose metabolism modulates cell growth/inhibition and suppresses T-cell function (18). In addition, the balance between iNOS and ARG is competitively regulated by Th1 and Th2 type-cytokines; Th1 cytokines induce iNOS, whereas Th2 cytokines induce ARG (19). One of the possible mechanisms to explain the impairment of antitumor immunity in patients with RCC is the well documented shift from Th1 to Th2 cytokine response (20). This shift may prompt the tumor microenvironment to produce high levels of ARG and polyamines instead of initiating an iNOS-dependent production of NO that could be characterized by the lack of Th1 responses in order to survive $(21 ; 22)$ Recently, we demonstrated that murine RCC cell lines with high levels of ARG2 expression are associated with L-arginine depletion resulting in induced T-cell dysfunction and increased tumor growth (23).

For many years, treatment with IFN $\gamma$ has shown minimal or no activity in patients with RCC. Since the combination of IFN $\gamma$ and IFN $\alpha$ treatment reflected a response rate similar to IFN $\alpha$ alone, the latter has been the treatment of election for RCC patients for many years (24). This observation is striking since IFN $\gamma$ has the most potent immunomodulatory activity among the interferons (25-27), indicating that the mechanisms of action of IFN $\gamma$ are complex, not well understood, and deserve to be re-visited in the context of tumor resistance and tumor microenvironment.

The present study focuses on the mechanisms by which IFN $\gamma$ can modulate L-arginine metabolism by shifting ARG-dependent cell proliferation to growth inhibition by inducing iNOS and NO production. Understanding these mechanisms will facilitate the development of new, effective, pharmacological strategies that interfere with L-arginine metabolism to control and eliminate RCC in affected patients.

\section{MATERIALS AND METHODS}

\section{Cell lines, reagents and culture conditions}

For this study, three murine RCC (mRCC) cell lines were used: SIRCC-1.2 (CL-2) and SIRCC 1.19 (CL-19) cells of induced origin (28) and Renca cells of spontaneous origin, kindly provided by Dr. Robert $\mathrm{H}$. Wiltrout (NCI). Cells were maintained at $37^{\circ} \mathrm{C}$ in continuous cell culture in RPMI-1640 containing 1,140 $\mu \mathrm{M}$ L-arginine (Lonza Inc., Walkersville, MD) and supplemented with $10 \%$ fetal bovine serum (Hyclone, Logan, UT), 25 mM HEPES, 4 mM L-glutamine, 100 units/ml of penicillin/streptomycin, $1 \mathrm{mM}$ non-essential amino acids, and $1 \mathrm{mM}$ sodium pyruvate (Lonza, Inc.). Recombinant mouse IFN $\gamma$ (rmIFN $\gamma$ ) purchased from R\&D Systems, Minneapolis, MN was used to determine its effect on iNOS induction and cytostasis on mRCC cells $(10 \mathrm{U} / \mathrm{ml})$. The inhibitor of iNOS, NG-monomethyl-L-arginine (L-NMMA) (EMD-Calbiochem, Gibbstown, NJ), was also titrated to determine the optimal inhibitory conditions $(1 \mathrm{mM})$. The experiments were performed by plating $3 \times 10^{5}$ cells in six-well plates which were allowed to attach for $24 \mathrm{~h}$ (this cell concentration allow the cells to survive in culture up to $120 \mathrm{~h}$ ). Fresh media containing IFN $\gamma$ and L-NMMA (Time 0) were added to the cells and cultured at 2, 4, 6, 24, 48, and 72 $\mathrm{h}$. At the different time points, supernatants were collected and cells were harvested using $0.05 \%$ Trypsin/EDTA (Sigma, St. Louis, MO) to perform the different assays. The protein concentration was determined by using the BCA protein assay kit (Pierce Biotechnology Inc., Rockford, IL). Cell extracts were stored at $-70{ }^{\circ} \mathrm{C}$ until used for western blots.

\section{Arginase activity}

Freshly prepared cytoplasmic extracts from cultured mRCC cells before and after treatment with IFN $\gamma$ were tested for ARG activity by the conversion of L-arginine to L-ornithine (nanomoles/106 cells/hour), as described elsewhere (29).

\section{Western blot}

Equal amounts of cell extract protein (25 
$\mu \mathrm{g} /$ lane) were electrophoresed in $8 \%$ Tris-glycine gels (Invitrogen, Carlsbad, CA) and transferred to polyvinylidiene difluoride (PVDF) membranes (Invitrogen). Immunoblotting was performed with antibodies for ARG2 (1:500), iNOS (1:200) (Santa Cruz Biotech, Santa Cruz, CA), and GAPDH $(1: 10,000)$ (Fitzgerald Industries International, Acton, MA). Detection was achieved by horseradish peroxidase-conjugated antibodies (1:3000, Santa Cruz) and an enhanced chemiluminescent kit (ECL, GE Healthcare, Piscataway, NJ). ARG2 and iNOS protein bands were visualized on X-OMAT AR films (Kodak, Rochester, NY).

\section{Reverse Transcription-PCR analysis}

Total RNA from $1 \times 10^{6}$ cells was extracted using TRIzol (Invitrogen), treated with DNase I (Invitrogen), and reverse transcribed using Superscript II (Invitrogen). PCR amplification was completed using primers for mouse iNOS and $\beta$-actin as follow: iNOS: forward, 5'-CTT CCG AAG TTT CTG GCA GCA GCG-3', reverse, 5'-GAG CCT CGT GGC TTT GGG CTC CTC-3', and $\beta$-actin forward 5'-CCA GAG CAA GAG AGG TAT CC-3', reverse 5'-CTG TGG TGG TGA AGC TGT AG-3'. The expected sizes of amplified fragments were iNOS $459 \mathrm{bp}$, and $\beta$-actin $436 \mathrm{bp}$. PCR products were visualized in ethidium bromide $1 \%$ agarose gels.

\section{Assessment for cell growth and survival}

Cell growth and viability was determined by using the previously described MTT assay (30). Briefly, different cell lines were plated at $1 \times 10^{4}$ /well in 24-well plates and treated with IFN $\gamma$. At 24, 48, and $72 \mathrm{~h}$, cells were incubated with MTT $(0.5 \mathrm{mg} / \mathrm{ml})$ for 4 $\mathrm{h}$ at $37^{\circ} \mathrm{C}$. Then, an equal volume of $0.04 \mathrm{M} \mathrm{HCl}$ in isopropanol was added to the wells and incubated for $3 \mathrm{~h}$ to dissolve the accumulated crystals of formazan. Absorbance was measured at $570 \mathrm{~nm}$ with a reference wavelength of $650 \mathrm{~nm}$ using a Benchmark Plus plate reader (Bio-Rad, Hercules, CA). Readings obtained from treated cells were compared with untreated controls in triplicate.

\section{DNA fragmentation}

Cell lines were treated with IFN $\gamma$ or untreated for 24, 48, and $72 \mathrm{~h}$. At each time point, the cells were harvested by trypsinization and washed once with phosphate buffered saline (PBS). Fragmented DNA was isolated using a DNA isolation kit (Qiagen, Valencia, CA) according to the manufacturer's instructions. Eluted samples containing DNA were electrophoresed on a $2 \%$ agarose gels (Life Technologies, Grand Island, NY) containing $0.5 \mu \mathrm{g} / \mathrm{ml}$ solution of ethidium bromide. DNA bands were visualized under
UV and exposed to photography.

\section{Cell cycle analysis}

For DNA content analysis, $1 \times 10^{6}$ cells were treated with IFN $\gamma$ for 24 and $48 \mathrm{~h}$. The cells were harvested by trypsin digestion, collected by centrifugation, and fixed in $70 \%$ ethanol / phosphate buffered saline for at least $12 \mathrm{~h}$ at $4^{\circ} \mathrm{C}$. After $100 \mu \mathrm{L}(1 \mathrm{~g} / \mathrm{L})$ of RNase treatment, cells were stained with $0.5 \mu \mathrm{g} / \mathrm{ml}$ propidium iodide. Cells were examined by flow cytometry using a LSR II (Becton-Dickinson, USA). The percentage of cells in each phase of the cell cycle was analyzed using Modfit software (Verity, Software House, Topsham, ME).

\section{Determination of Nitric oxide production}

Nitrite accumulation in cell culture medium under defined conditions was used as an indirect determination of NO production and measured by a colorimetric assay based on the Griess reaction. Briefly, $200 \mu \mathrm{L}$ of the culture supernatants were mixed with $200 \mu \mathrm{L}$ of Griess reagent [one part $0.1 \%$ $\mathrm{N}$-(1-naphtyl) ethylene-diamine dihydrochloride and one part $1 \%$ sulfanilamide] in $5 \%$ concentrated $\mathrm{H}_{3} \mathrm{PO}_{4}$ for $10 \mathrm{~min}$ at room temperature. The absorbance was measured at $540 \mathrm{~nm}$ in a Benchmark Plus plate reader (Bio-Rad). The readings were compared to a standard curve for sodium nitrite with a lower detection limit of $1 \mu \mathrm{mol} / \mathrm{L}$ nitrite. In order to confirm that the formed nitrites were derived from iNOS induction, cells were cultured in the presence of the iNOS inhibitor L-NMMA.

\section{Amino acid detection}

High performance liquid chromatography (HPLC) was conducted on deproteinized conditioned media labeled with $O$-phtaldialdehyde (OPA). Analytes were eluted with $100 \mathrm{mM}$ sodium acetate buffer, $\mathrm{pH} 5.0$, with a linear gradient consisting of methanol $(100 \%)$ and acetonitrile $(100 \%)$. The analytes in the samples were calculated on the basis of standard curves of known amounts.

\section{Cytokine measurement}

Cytokines were measured in tissue culture supernatants released from cells at the different time points using Th1/Th2 panel Bio-Plex cytokine assay (Bio-Rad Laboratories, Hercules, CA) as described previously following the manufacturer's instructions (31). The samples were analyzed for IL-2, IL-4, IL-5, IL-10, IL-12 (p70), GM-CSF, IFN $\gamma$, TNF $\alpha$, IL1 $\beta$, IL6, and VEGF on a Bio-Rad 96-well plate reader using the Bio-Plex Suspension Array System and Bio-Plex Manager software (Bio-Rad). 


\section{Statistical analysis}

Statistical analyses were completed in SAS v9.1 (SAS Institute, Cary, NC). For each cell line, nitrite concentration, proliferation, and ARG activity data were analyzed by mixed models for unequal variances. Two-way ANOVA models were used with time and experimental conditions (basal/IFN $\gamma$, control/IFN $\gamma$, and IFN $\gamma+$ LNMMA) as factors. After IFN $\gamma$ treatment, each experimental condition was tested at each time point. Multiple testing was conducted at the $5 \%$ level using the Tukey procedure. Least squares means and corresponding standard errors were obtained.
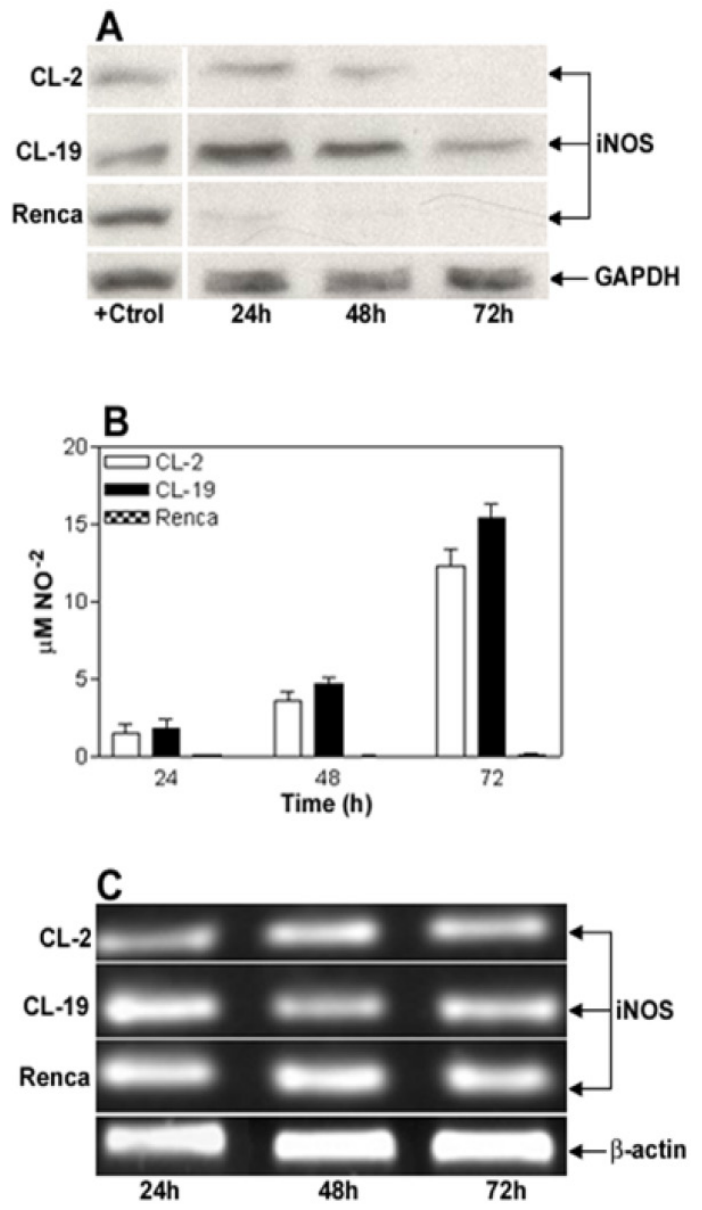

Figure I. Characterization of iNOS expression and iNOS activity in murine RCC cell lines cultured in normal conditions. (A) Representative Western blot analysis for iNOS (I $30 \mathrm{kDa}$ ) and GAPDH (35 kDa) in CL-2, CL-19 and Renca cells cultured in normal conditions for 24,48 , and $72 \mathrm{~h}$. Twenty five $\mu \mathrm{g}$ of total protein was loaded per line. RAW 264.7 cells stimulated with LPS plus murine IFN $\gamma$ were used as positive control (+Ctrl) for iNOS protein. (B) Nitrite production in the 3 cell lines was determined by Greiss reaction in culture media supernatants collected after 24,48 , and $72 \mathrm{~h}$ in culture. Results are the mean \pm SE of triplicates of five different separate experiments. (C) Reverse transcription-polymerase chain analysis of iNOs mRNA expression. The result of a representative experiment is shown; similar results were obtained in at least three experiments. The expected sizes of amplified fragments were $459 \mathrm{bp}$ for iNOS and 436 bp for $\beta$-actin.

\section{RESULTS}

\section{iNOS protein expression and NO production differs in $\mathbf{m R C C}$ cell lines}

The basal expression level of iNOS protein and nitrite production in RCC cell lines CL-2, CL-19, and Renca, cultured in complete RPMI media for 24, 48, and $72 \mathrm{~h}$ was determined. As shown in Figure 1A, iNOS protein is detected at moderate levels in CL-2 and CL-19 during the time course of this experiment. In contrast, a complete absence of iNOS protein expression was observed in Renca cells. When supernatants were tested for NO release, a minimal and continued synthesis of nitrites ranging from $1.4 \pm 0.64$ $\mu \mathrm{M}$ at $24 \mathrm{~h}$ to $12.2 \pm 1.12 \mu \mathrm{M}$ at $72 \mathrm{~h}$ in the CL-2 cells and from $1.7 \pm 0.63 \mu \mathrm{M}$ up to $15.4 \pm 0.86 \mu \mathrm{M}$ in CL-19 cells was observed. Although low levels of iNOS are expressed in CL-2 and CL-19 in the absence of IFN $\gamma$, we were unable to detect nitrites released by iNOS activity at the level of detection available to us, before $24 \mathrm{~h}$. However, production of NO was not observed in Renca cells at any tested time point (Figure 1B). The absence of iNOS protein expression in Renca cells prompted us to test iNOS mRNA expression by reverse-transcriptase $\mathrm{PCR}$ in the aforementioned cell lines. As shown in Figure 1C, iNOS mRNA gene expression was similar in all three cell lines at the different time points of the experiments.

\section{IFN $\gamma$ increases iNOS protein levels and NO production in CL-2 and CL- 19 but not in Renca cells}

To determine the level of toxicity of IFN $\gamma$ on the cell lines, kinetic experiments using concentrations of IFN $\gamma$ ranging from 2.5 to $500 \mathrm{U} / \mathrm{ml}$ were performed (data not shown). In this system, it was observed that $10 \mathrm{U} / \mathrm{ml}$ of IFN $\gamma$ was the optimal concentration to induce iNOS expression and to stimulate NO production without a measurable toxic effect on the cells. IFN $\gamma$ concentrations higher than $15 \mathrm{U} / \mathrm{ml}$ were toxic to CL-2 and CL-19 cell lines, where a complete detachment of the cell monolayer was observed as early as $12 \mathrm{~h}$ (data not shown). Immunoblot analysis showed a maximal increase in the expression of immunoreactive iNOS protein in CL-2 and CL-19 cells at 24 hours, post-treatment. iNOS levels started to decrease at $48 \mathrm{~h}$ and reached basal levels at $72 \mathrm{~h}$ (Figure 2A). Interestingly, IFN $\gamma$ did not induce iNOS protein or cytostasis in Renca cells. This finding prompted us to examine iNOS gene expression pre- and post- IFN $\gamma$ treatment. Strikingly, iNOS mRNA was expressed in Renca cells at the same levels before and after treatment; this finding suggests a post-transcriptional 
regulation of iNOS expression. In contrast, IFN $\gamma$ treatment markedly enhanced levels of iNOS mRNA in CL-2 and CL-19 cell lines (Figure 2B). The increased iNOS mRNA and protein expressions in CL-2 and CL-19 cells are associated with the production of high levels of NO ranging from $59.7 \pm 2.0 \mu \mathrm{M}$ at $24 \mathrm{~h}$ to 85.6 $\pm 9.6 \mu \mathrm{M}$ at $72 \mathrm{~h}$ in CL-2 cells and from $42.4 \pm 5.3 \mu \mathrm{M}$ at $24 \mathrm{~h}$ to $71.9 \pm 9.9 \mu \mathrm{M}$ at $72 \mathrm{~h}$ in CL-19 cells (Table 1 ). As expected, production of $\mathrm{NO}$ was not observed in Renca cells throughout the course of the experiments. Minimum iNOS protein expression was observed in untreated cells (Figure 1A) that were used as control against treated cells.
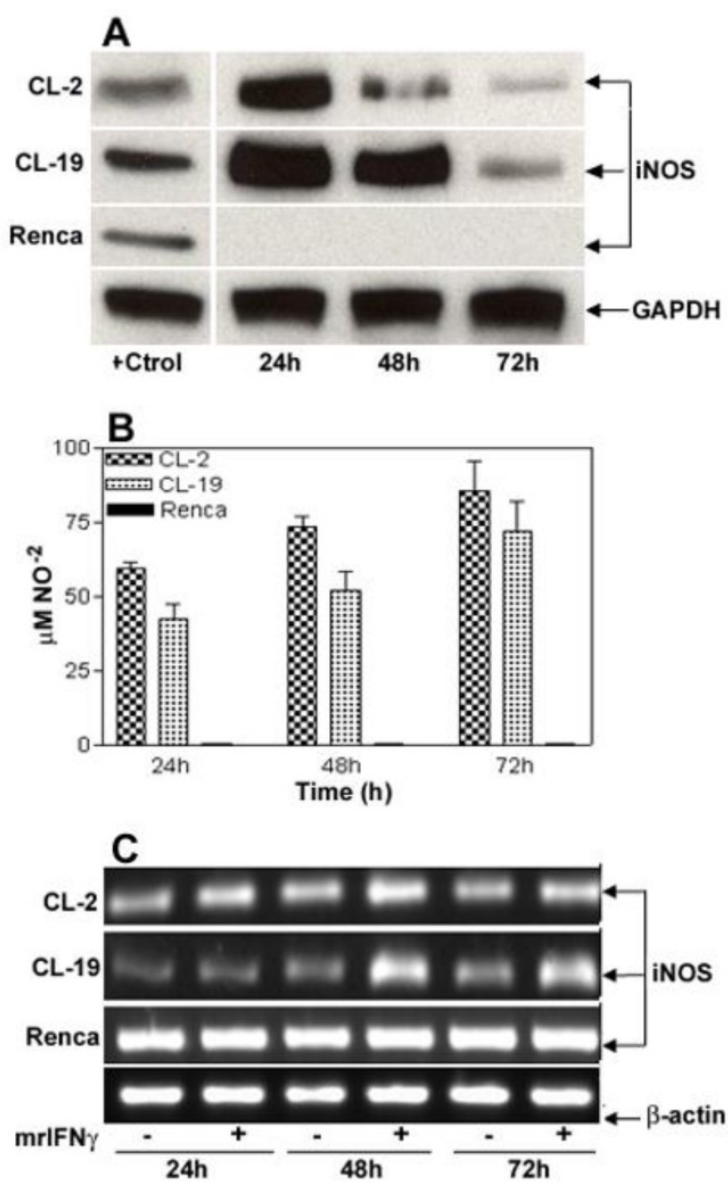

Figure 2. IFN $\gamma$-induced iNOS expression and iNOS activity in murine RCC cell lines. For reference, Figure IA can be used as untreated control for these experiments. (A) Time course of iNOS protein expression by Western blot after stimulation of cells for 24 , 48 , and $72 \mathrm{~h}$ with $10 \mathrm{U} / \mathrm{ml}$ of murine IFN $\gamma$. (B) Nitrite production in culture supernatants following stimulation with IFN $\gamma$. Values for nitrite production are expressed by mean \pm SE for three different experiments performed five different times. (C) Pattern of 24, 48, and $72 \mathrm{~h}$ iNOS mRNA induction (RT-PCR) in response to IFN $\gamma$ stimulation. Each Western blot and RT-PCR presented is from single experiment that is representative of three to five separate experiments.
Table I. Nitrite concentration ( $\mu \mathrm{M})$ in RCC cell lines of $\mathrm{NO}^{-2}$ before and after treatment with IFN $\gamma$. ' Means of 6 different experiments; ${ }^{2} \mathrm{SE} ;{ }^{*} \mathrm{p}$-values for significance $(p=0.000 \mathrm{I})$ between untreated and treated cells with IFN $\gamma$ for each cell line.

\begin{tabular}{lllllll}
\hline & CL-2 & \multicolumn{3}{c}{ CL-19 } & \multicolumn{2}{l}{ Renca } \\
\hline Time & -IFN $\gamma$ & +IFN $\gamma$ & -IFN $\gamma$ & +IFN $\gamma$ & \multicolumn{2}{l}{-IFN +IFN } \\
& & & & & $\gamma$ & $\gamma$ \\
$24 h$ & $1.4^{1} \pm$ & $59.7 \pm 2.01$ & $1.7 \pm 0.63$ & $42.4 \pm 5.29$ & 0 & 0 \\
& $0.64^{2}$ & & & & & \\
$48 \mathrm{~h}$ & $3.5 \pm 0.61$ & $73.3 \pm 3.79$ & $4.6 \pm 0.36$ & $52.0 \pm 6.69$ & 0 & 0 \\
$72 \mathrm{~h}$ & $12.2 \pm$ & $85.6 \pm$ & $15.4 \pm$ & $71.9 \pm$ & 0 & 0 \\
& $1.12^{*}$ & $9.62^{*}$ & $0.86^{*}$ & $9.93^{*}$ & & \\
\hline
\end{tabular}

IFN $\gamma$ induces NO-mediated cell death in CL-2 and CL- 19 cell lines that is abrogated by the iNOS inhibitor L-NMMA

The effectiveness of IFN $\gamma$ in inhibiting the proliferation of mRCC cell lines was assessed using MTT assays. As seen in Figure 3A, the addition of $10 \mathrm{U} / \mathrm{ml}$ of IFN $\gamma$ to $\mathrm{mRCC}$ cell lines significantly inhibited cell proliferation of CL-2 ( $p=0.008)$ and CL-19 ( $p=0.0001)$ after $48 \mathrm{~h}$ in culture when compared to untreated cells. Not surprisingly, no significant difference in proliferation $(p=0.091)$ was observed in Renca cells. As seen in Figure 3B, differences in cell morphology and cell growth in CL-2 and CL-19 treated cells were observed at 48 hours post-treatment; these effects were absent in Renca cells at the same time-point. To test whether IFN $\gamma$ inhibited cell proliferation and induced cell death through the endogenous production of NO, L-NMMA, a non-selective inhibitor of all NOS isoforms, was added to the cultures. Confirming the cell death resulting from NO production, L-NMMA completely reversed the killing effects of IFN $\gamma$ treatment (Figure 3A). NO production was also measured directly from the supernatants and showed that LNMMA completely inhibited the production of nitrites after stimulation with IFN $\gamma$ in CL-2 and CL-19 cell lines $\left.{ }^{* * *} p<0.0001\right)$ as seen in Figure 4.The results are most easily interpreted to indicate that the endogenous production of NO by IFN $\gamma$ treatment has a potent inhibitory effect on tumor cell survival and proliferation. Only endogenous NO inhibited cell proliferation and survival because control experiments, where nitrites were added exogenously to the media, showed no effect on cell survival (data not shown). 

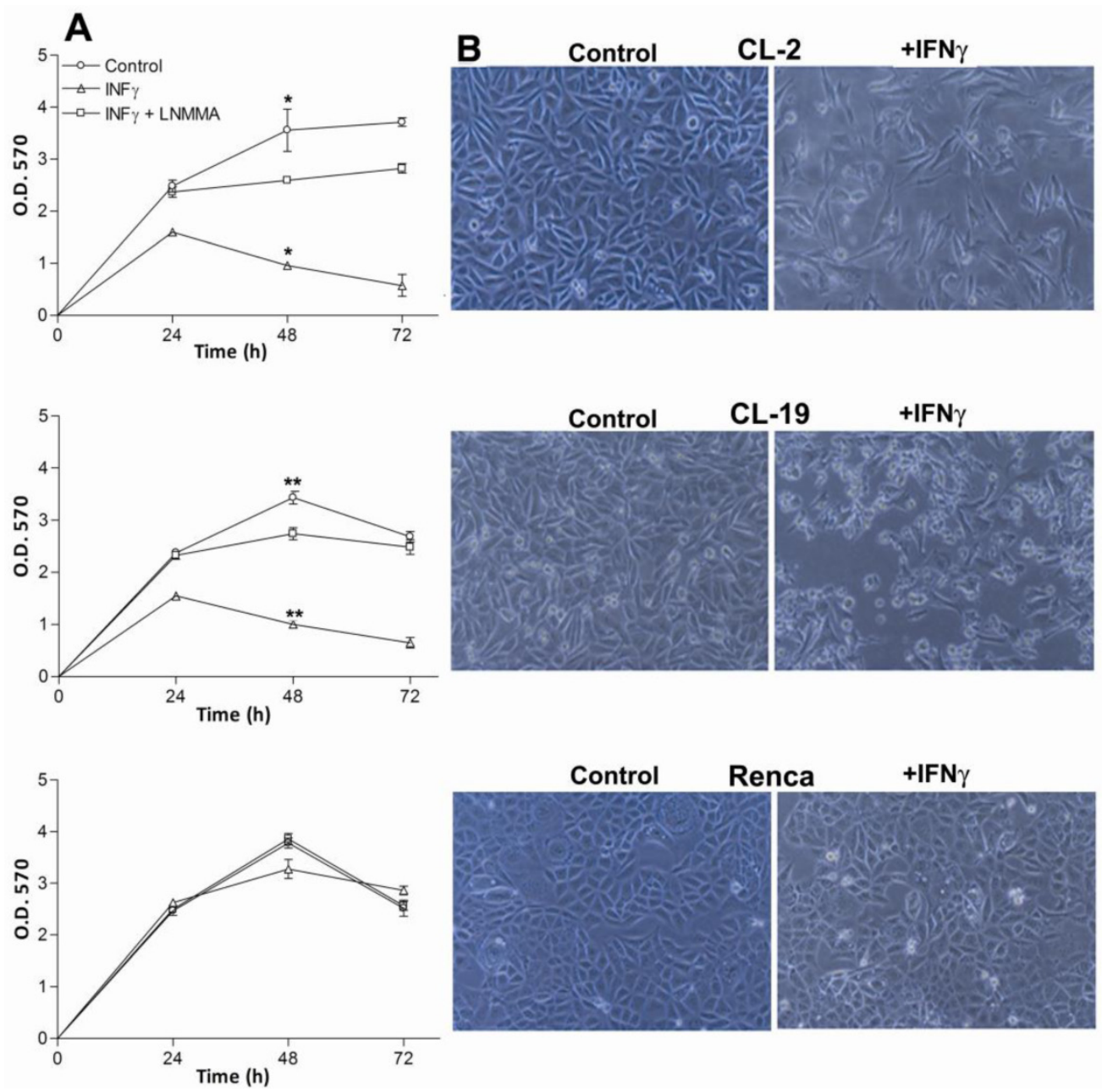

Figure 3. Effect of IFN $\gamma$ and LNMMA on CL-2, CL- 19 and Renca cell proliferation. (A) Three hundred thousand cells from CL-2, CL- 19 and Renca were seeded in six well plates and cultured in presence or absence of IFN $\gamma(I 0 \mathrm{U} / \mathrm{ml}$ ) or iNOS inhibitor LNMMA (ImM). Cell proliferation was measured at 24,48 , and $72 \mathrm{~h}$ using the MTT assay. The results are expressed as O.D (570) means \pm SE of triplicate determinations from five independent experiments. Significant differences in proliferation were observed between control and IFN $\gamma$ treated $C L-2(* \mathrm{P}=$ $0.0084)$ and $C L-19$ (** $=0.000$ I) cells respectively. (B) Morphological changes and inhibition of cell proliferation in the CL-2, CL-19 and Renca cells before and after treatment with IFN $\gamma$. Microscopic images of mRCC cells after treatment with IFN $\gamma$ were taken at $48 \mathrm{~h}$. Photographs were taken under phase contrast at $100 x$ magnification.

\section{Effects of IFN $\gamma$ on DNA fragmentation and cell cycle in the cell lines}

Apoptosis is characterized by DNA fragmentation; therefore, DNA was isolated from the three cell lines after treatment with IFN $\gamma$ at 24,48 , and $72 \mathrm{~h}$ and tested for its integrity. The results shown in Figure 5A indicate that the cytostatic effects of endogenous $\mathrm{NO}$ production do not result in an increase in DNA fragmentation in any of the cell lines. An analyses of the cell cycle profile by flow cytometry (Figure 5B) also indicated that IFN $\gamma$ treatment did not induce apoptosis in CL-2 and CL19 cells; however, CL-2 and CL-19 cells accumulated at $\mathrm{G}_{2} / \mathrm{M}$ (4N DNA content). Therefore, growth inhibition of these cell-lines by IFN $\gamma$ may be a result from the cell-cycle arresting at
$\mathrm{G}_{2} / \mathrm{M}$. No changes in cell cycle were observed in response to IFN $\gamma$ in Renca cells.

\section{Effect of IFN $\gamma$ treatment on arginase activity}

The differential expression of ARG2 previously observed (23) led us to test whether IFN $\gamma$ treatment affected ARG activity and L-arginine concentrations. Cytoplasmic extracts of untreated and treated cells with IFN $\gamma$ were isolated at 24, 48, and $72 \mathrm{~h}$ and tested for ARG activity. The three cell lines express similar basal ARG activity at $24 \mathrm{~h}$. After $48 \mathrm{~h}$, there was a slight increase in CL-2 and Renca cells, while a marked increase in CL-19 cells was observed, as illustrated in Figure 6. Immunoblot analysis for ARG2 protein confirmed these results (data not shown). The increase in basal ARG activity within the culture times 
is observed only in the absence of media changes during the time course of the experiments. Changes were not observed in both untreated and treated cells with IFN $\gamma$. Further, treatment with IFN $\gamma$ produced a significant decrease in ARG activity in CL-2 $(p=0.048)$ and CL-19 ( $p=0.003)$ cells after $48 \mathrm{~h}$, an effect that was only observed in Renca cells $(p=0.031)$ after $72 \mathrm{~h}$ in culture (Figure 6). Collectively, these data indicate that IFN $\gamma$ interferes with ARG activity in the three cell lines, perhaps by inhibiting transcription of the ARG2 gene.
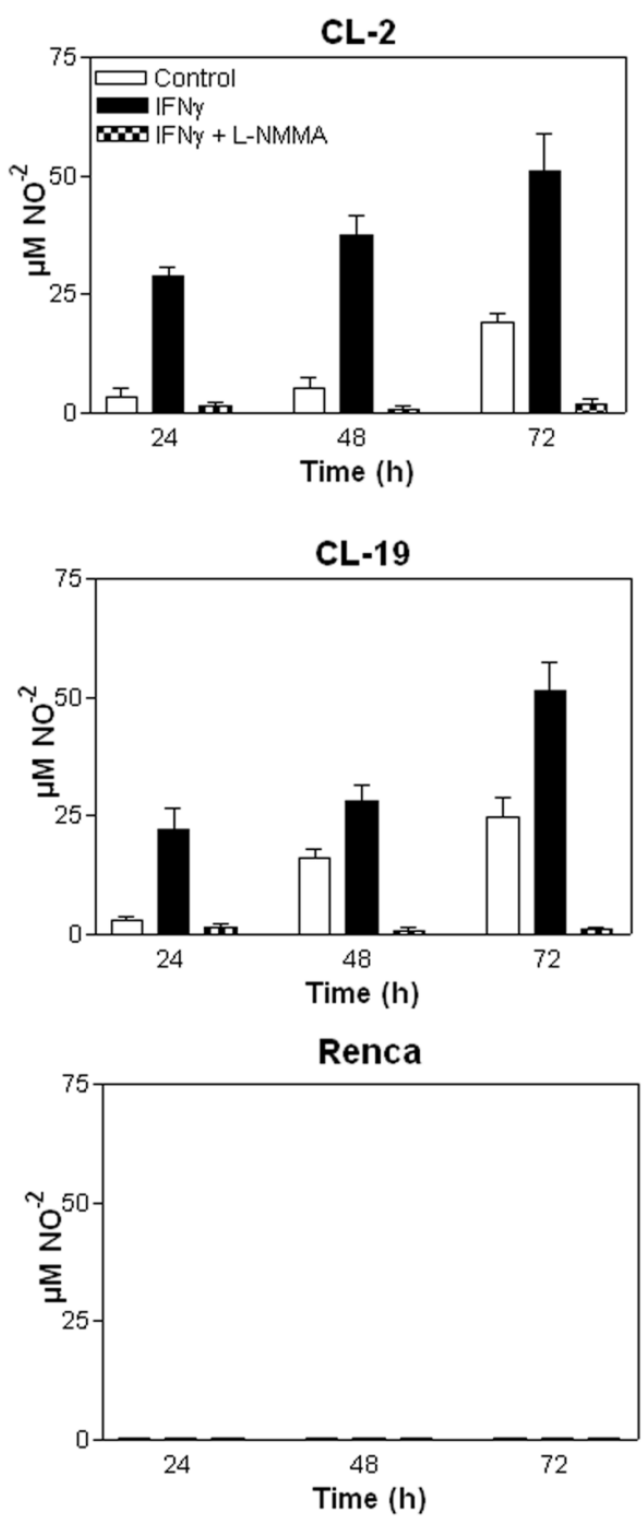

Figure 4. Nitrite (NO-2) production measured in $\mathrm{mRCC}$ cells after treatment with IFN $\gamma$ and IFN $\gamma$ plus LNMMA. Average nitrite concentration between untreated and treated cells with IFN $\gamma$ over time in (A) CL-2 $(* p=0.003)$ and $(\mathbf{B}) \mathrm{CL}-19(* * \mathrm{p}=0.037)$ at 48 and $72 \mathrm{~h}$ respectively. Significant reduction of nitrite production $(* * *$ $\mathrm{p}<0.000 \mathrm{I}$ ) in CL-2 and CL- 19 cells after the addition of iNOS inhibitor LNMMA. (C) Nitrite values in Renca cells after IFN $\gamma$ treatment. Results are the mean \pm SE of triplicates of five different separate experiments.
Effect of IFN $\gamma$ in $\mathrm{mRCC}$ cell lines on L-arginine concentration and its effect on the production of NO and citrulline

Since L-arginine is the common substrate for iNOS and ARG, we wanted to explore the effect of IFN $\gamma$ treatment on L-arginine consumption by HPLC. The standard concentration of L-arginine in the cell culture media was $1,140 \mu \mathrm{M}$ for all experiments. As seen in Figure 6A, in the first $24 \mathrm{~h}$, the depletion of L-arginine was similar in the three cell lines. The CL-19 cell line, which expressed the highest levels of ARG activity, significantly depleted the media of L-arginine concentrations by 6-fold $(450 \mu \mathrm{M})$ at $24 \mathrm{~h}$, 7-fold $(296 \mu \mathrm{M})$ at $48 \mathrm{~h}$, and 9-fold $(110 \mu \mathrm{M})$ at $72 \mathrm{~h}$; however, no major changes in L-arginine content were observed in CL-2 and Renca cells at 48 and $72 \mathrm{~h}$ in culture. The addition of IFN $\gamma$ to the cultures significantly $(p=0.0002)$ decreased the rate of depletion of L-arginine in CL-19 at $72 \mathrm{~h}$ when compared to untreated cells at the same time point (Figure 7A). The levels of L-arginine in CL-2 and Renca cells remained unchanged after the treatment. Concurrent with the depletion of L-arginine in the three cell lines, there was an increase in L-ornithine production that was abrogated $(p=0.018)$ after $72 \mathrm{~h}$ of IFN $\gamma$ treatment in CL-19 cells when compared to CL-2 and Renca as illustrated in Figure 7B. As iNOS catalyzes the conversion of L-arginine to equimolar quantities of $\mathrm{NO}$ and citrulline, the samples were analyzed for citrulline after treatment with IFN $\gamma$. Citrulline concentrations increased significantly in a time-dependent manner in CL-2 $(p=0.0001)$ and CL-19 $(p=0.0013)$ at $48 \mathrm{~h}$, whereas no increase was observed in Renca cells (Figure 7C). The data obtained for citrulline were nearly identical to the values obtained for nitrites seen in Figure 4, after IFN $\gamma$ treatment. Together, these results suggest that IFN $\gamma$ shifts the L-arginine metabolic pathway towards NO and citrulline production, consequently inhibiting RCC cell proliferation.

\section{Cytokine Production in $\mathrm{mRCC}$ cell lines}

In order to gain insights into the biology of mRCC cell lines and to determine their ability to produce cytokines, we tested for IL-2, IL-4, IL-5, IL-10, IL-12 (p70), GM-CSF, IFN $\gamma$, TNF $\alpha$, and VEGF concentrations in the culture supernatants. Figure 8 shows the cytokine expression in the three cell lines at $48 \mathrm{~h}$. We choose $48 \mathrm{~h}$ since the maximum production of these cytokines was observed at this time point. Moderate concentrations of IL-1 $\beta$ and IL- 6 and high concentrations of VEGF and TGF $\beta$ were observed in all three cell lines. It appears that IFN $\gamma$ treatment had a significant effect in the production of IL-1 $\beta$ and IL-6 
$(\mathrm{p}=0.001$ and $\mathrm{p}=0.028)$ in CL-2 and IL-1 $\beta$ ( $\mathrm{p}=$ 0.09 ) in CL-19 cells (Figure 8). This effect was not observed in Renca cells. Although, the amount of VEGF and TGF $\beta$ was considerably higher in all three cell lines at basal level, treatment with IFN $\gamma$ had no significant effect on the concentrations of these cytokines.

Figure 5. Effect of IFN $\gamma$ treated cells on apoptosis and cell cycle. (A) Cells were plated for I day and then cultured in media containing IFN $\gamma$. DNA was extracted and subjected to DNA fragmentation ladder analysis. Data are representative of three independent experiments with similar results. (B) Analysis of cell cycle progression in untreated and treated $\mathrm{mRCC}$ cell lines with IFN $\gamma$. After 24,48 , and $72 \mathrm{~h}$ cells were analyzed for DNA content by flowcytometry. A representative experiment performed at $48 \mathrm{~h}$ indicate the distribution of the cells in GI, S, and G2/M phases of the cell cycle.
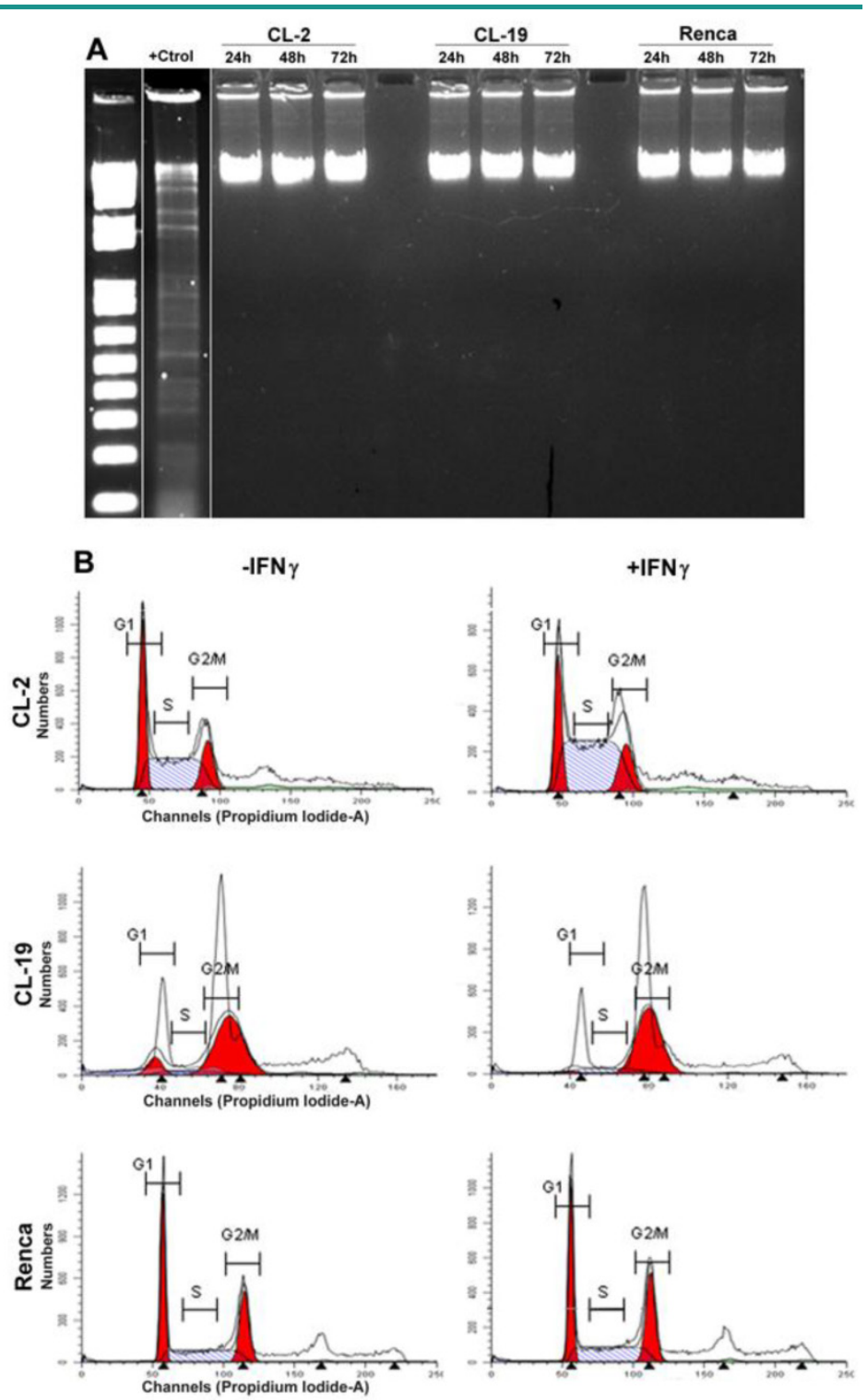

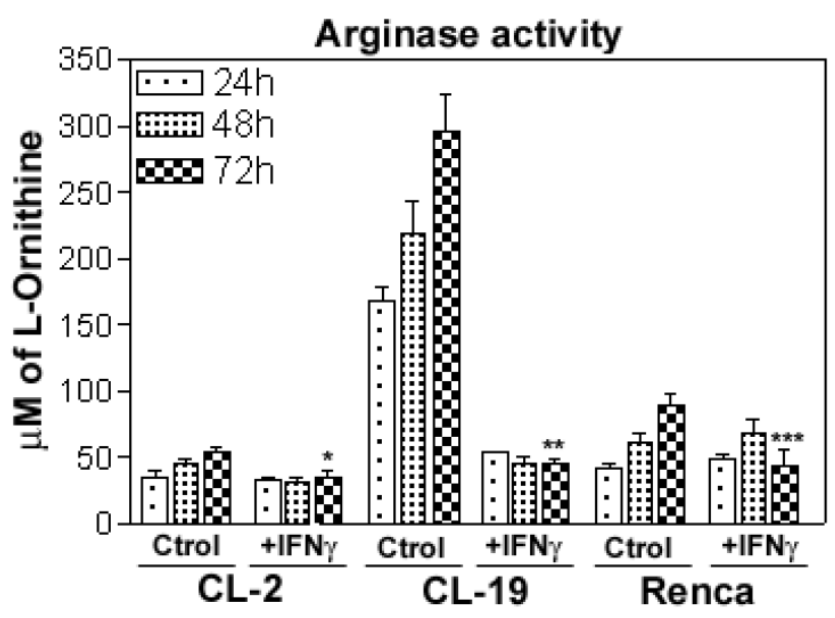

Figure 6. The effects of IFN $\gamma$ on the induction of arginase activity in the $\mathbf{m R C C}$ cell lines. Cells were treated with $10 \mathrm{U} / \mathrm{ml}$ of IFN $\gamma$ for 24,48 , and $72 \mathrm{~h}$ and tested for arginase activity (conversion of L-argine to L-ornitine by arginase). As compared to untreated cells (Ctrl) significant reduction of ARG activity is observed: $C L-2(* p=0.02) C L-19(* * p=0.0008)$ and Renca $(* * * p=0.03)$ at $72 \mathrm{~h}$. The data represent the mean $\pm S E$ of triplicate determinations from five separate experiments. 

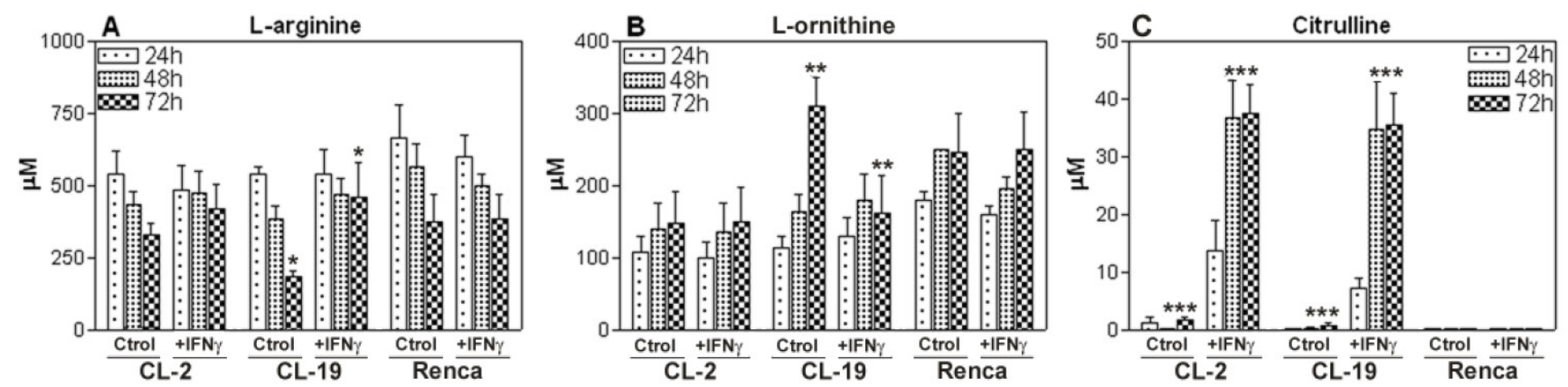

Figure 7. L-arginine, L-ornithine, and citrulline levels. Culture supernatants of CL-2, CL- 19 and Renca cells untreated and treated with IFN $\gamma$ were collected at 24,48 , and $72 \mathrm{~h}$ and analyzed by HPLC after deproteinization with methanol and derivatization with OPA. Standards for $\mathrm{L}$-arginine, L-ornithine, and citrulline in methanol were run with each experiment. Asterisks show significant differences between untreated and treated cells. (A) CL-19 L-arginine (* $p=0.0002)$, (B) $C L-19$. L-ornithine (** $p=0.0183$ ), and (C) $C L-2$ and $C L-19$ citrulline (*** $p=0.0001)$. The results are expressed as mean \pm SE of duplicate determinations from four independent experiments.
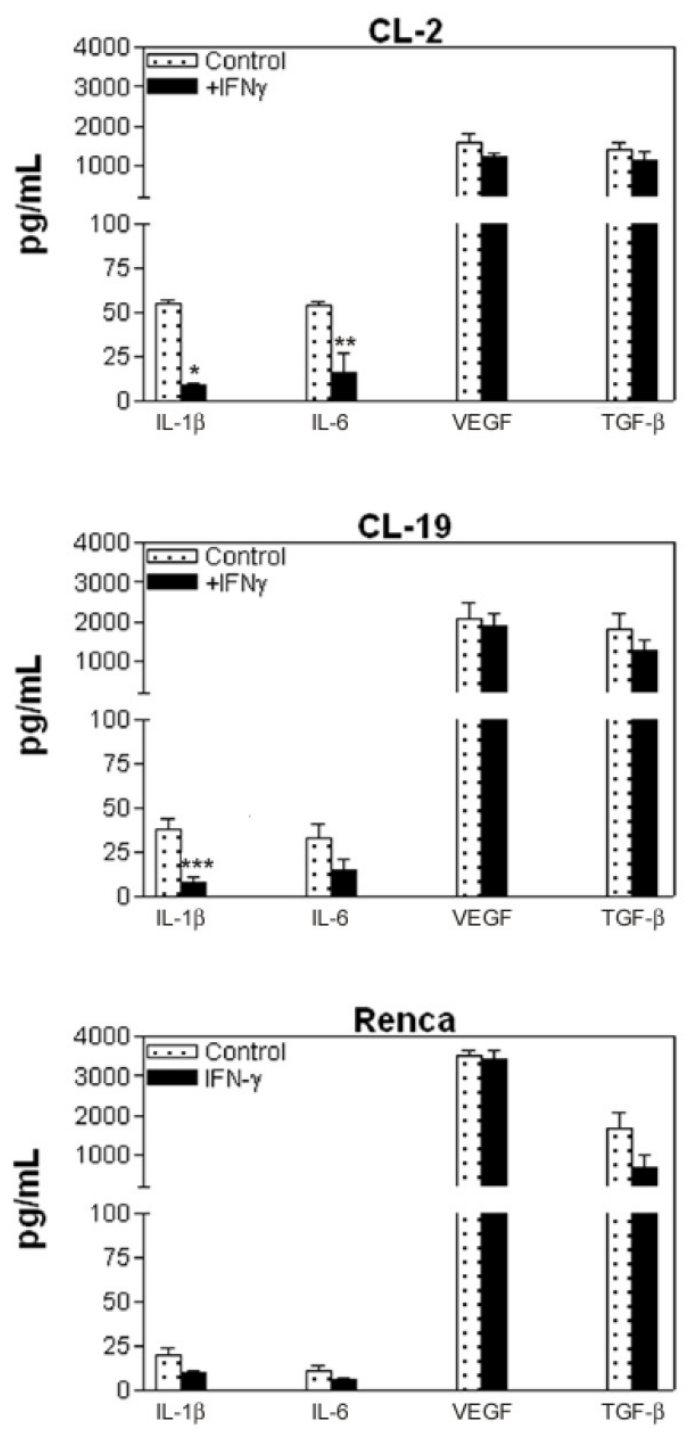

Figure 8. Cytokine profile in supernatants of $\mathrm{mRCC}$ cell lines. The cell lines were seeded in 6 well plates and treated with IFN $\gamma$ $(\mathrm{IOU} / \mathrm{ml})$ for 24,48 , and $72 \mathrm{~h}$. Supernatants were collected and assayed using a ThI/Th2 panel Bio-Plex cytokine assay. IL-I $\beta$, IL-6, VEGF, and TGF $\beta$ levels are shown. Treatment with IFN $\gamma$ has a significant inhibitory effect in CL-2 cells production of IL-I $\beta$ and IL-6 in CL-2 (* $\mathrm{p}<0.00$ I; ** $\mathrm{p}=0.002)$ and IL-I $\beta$ in CL-I9 $(* \mathrm{p}=0.009)$. Data are representative of experiments at $48 \mathrm{~h}$ of at least 3 independent experiments.

\section{DISCUSSION}

In this study, we reported the following: 1) a new mechanism to define the cytostatic role of NO in the inhibition of RCC cell proliferation; 2) the effect of IFN $\gamma$ in modulating L-arginine metabolism and cytokine production; 3 ) the resistance of certain RCC cell lines (Renca) to IFN $\gamma$ treatment; and, 4) new insights into the mechanisms by which RCC tumors may locally and systemically shut down an important effector arm of the immune response. IFNs have been widely used in preclinical models and in immunotherapy trials for RCC (32;33). The activity of monotherapy with IFN $\alpha$ in metastatic RCC has been extensively evaluated $(34 ; 35)$ with disappointing and controversial results. However, trials using a combination of IL-2 and IFN $\alpha$ indicated a clinically useful antitumor activity with a $15 \%$ overall response $(36 ; 37)$. In contrast, therapy with the single agent IFN $\gamma$ has shown discouraging results in patients with RCC. Although preliminary studies suggested the benefits of IFN $\gamma$ treatment (38), only a $4.4 \%$ overall response has been seen in phase III studies indicating that IFN $\gamma$ alone has no major impact on RCC treatment (39). 
These results are striking since many IFN $\gamma$-mediated properties (e.g. anti-proliferative, apoptotic, and anti-angiogenic activity) have been attributed to this cytokine (40;41).

Our study was aimed to determine the mechanism(s) by which IFN $\gamma$ is capable of inducing growth inhibition of murine RCC cell lines. Previously, we reported that murine CL-2, CL-19, and Renca cell lines have different levels of ARG2 expression that appear to be associated with the enhancement of cell proliferation (23).The results indicate a need for the tumor cells to use ARG2 to metabolize L-arginine for the synthesis of polyamines to promote cell growth. Conversely, NO is a free radical that, at low concentrations, acts as single signal transducer whereas at higher concentrations can act as a cytotoxic/cytostatic defensive mechanism against pathogens and perhaps tumors (42). In our study, we found that RCC cell lines in the logarithmic phase of proliferation expressed low iNOS protein levels and low concentrations of $\mathrm{NO}$ as measured by the production of nitrites $(15-20 \mu \mathrm{M})$, whereas ARG2 activity was highly present in the 3 cell lines. These results indicate that low iNOS and high ARG2 activity favor the growth of the cell lines and are supported by previous studies showing that high expression of ARG can inhibit iNOS activity and NO production (43-45). We believe this could be a mechanism used by tumor cells to survive by directly avoiding the cytostatic effects of NO.

Since IFN $\gamma$ is a potent inducer of iNOS, we wanted to determine in vitro the mechanism(s) by which this cytokine is capable of inhibiting RCC cell proliferation. We successfully demonstrated that iNOS induction within the tumor cells in response to IFN $\gamma$ caused a robust and sustained accumulation of endogenous NO that resulted in an $80-85 \%$ growth inhibition of CL-2 and CL-19 cell lines (Figure 3). This effect was abrogated by the addition of the iNOS inhibitor, L-NMMA, showing that the reduction in cell growth was mediated by NO. It is possible that the NO-mediated cytostatic effects observed in our in vitro model could produce a different outcome in an in vivo model due to the presence of NO-producing cells infiltrating the tumor microenvironment. Here, we found that the cytostatic effect of NO in RCC cell lines was not due to apoptosis as demonstrated by others $(46 ; 47)$, but rather by a cell cycle arrest at the $\mathrm{G}_{2} / \mathrm{M}$ phase. This possibly could be mediated by the transcriptional modulation of cyclins and/or cyclin-dependent kinases as seen in breast cancer cell lines and T cells $(48 ; 49)$. Since the growth-inhibitory activity of IFN $\gamma$ appears to be accompanied by the inhibition of ARG activity in CL-2 and CL-19 cells
(Figure 5), we are suggesting that this inhibition could be partially responsible for the growth-inhibitory effects of IFN $\gamma$ in addition to the major cytostatic effects of NO. The importance of ARG and/or NO in the growth-inhibition of RCC cells needs to be explored further by possibly using ARG and iNOS-KO mice. Altogether, our data suggest that ARG2 and iNOS can be modulated in a coordinated fashion by IFN $\gamma$ to counterbalance tumor growth and tumor inhibition. Lately, NO has emerged as a potential anti-proliferative agent capable of overcoming tumor cell resistance to conventional therapeutic agents. Despite the relative beneficial effect of IFN $\gamma$-NO induction which inhibits RCC proliferation, a substantial percentage $(15 \%)$ of the cells failed to respond to IFN $\gamma$ treatment. For the first time, our results show that a certain subpopulation of RCC cells develop a mechanism of resistance to specific cytostatic stimuli that could largely explain the commonly observed lack of response to IFN $\gamma$ in clinical trials. Mechanisms of resistance have been associated with IFN $\alpha$ defective Jak/Stat signaling pathways (50-52) that could be similar with IFN $\gamma$.

Interestingly, in our study, we showed that Renca cells which, upon stimulation with IFN $\gamma$ express iNOS mRNA, did not express iNOS protein or NO production (Figure 2). Different mechanisms have been postulated to explain the lack of iNOS expression, but a novel finding has shown that loss of iNOS protein expression is exerted by translational inhibition specifically mediated by miR-146a (50). The goal of this study was not to understand the control of iNOS expression at the translational level, but to highlight that different RCC cell types can vary in their sensitivity to IFN $\gamma$ and, therefore, to NO. These findings will have a high translational relevance because permitting us to identify RCC cells better and to determine their sensitivity to IFN treatment. It is possible that human RCC could present with similar characteristics to those seen in Renca cells. Therefore, these cells (or patients) will not benefit from IFN $\gamma$ treatment not because IFN $\gamma$ does not work but rather because these cells found a way to become resistant to this cytokine as a mechanism of survival. Therefore, in patients, the identification of resistance to INF treatment could be extremely important for a more personalized and effective treatment of RCC.

Production of either stimulatory or inhibitory cytokines by infiltrating or neoplastic cells may have more of an impact on the development of an effective anti-tumor response than in the promotion of tumor growth. When we tested cytokine production before IFN $\gamma$ treatment, IL-1 $\beta$, IL-6, TGF $\beta$, and VEGF were the 
most predominant cytokines in all 3 cell lines. Our results showed a parallel effect of IL-1 $\beta$ and IL- 6 reduction (CL-2 and CL-19) with the inhibitory effects of $\mathrm{NO}$, an effect that could be associated with low ARG activity. Conversely, IFN $\gamma$ did not have an effect on the production of VEGF and TGF $\beta$, indicating that the inhibition of these cytokines can be mediated by other signaling pathways and that their presence can contribute to the maintenance of tumor growth and angiogenesis. A combination therapy of IFN $\gamma$ with other drugs (e.g. sunitinib) which targets VGEF receptors could advance the treatment of RCC.

In summary, we provided new evidence that an improved understanding of IFN $\gamma$ biology in the inhibition of tumor cell proliferation will provide new insights regarding the use of this cytokine, not only for the treatment of RCC, but for the treatment of other tumors where the use of interferons is indicated. Although the development of agents targeting VEGF and mTOR pathways has provided chemotherapeutic agents that are more active and less potentially toxic than interferons, regardless of the specific target, the end point of these therapies relies upon the induction of Th1 responses (mainly IFN $\gamma$ expression). Our results indicate that IFN $\gamma$ can play a key role in modulating L-arginine metabolism by inhibiting ARG activity and by enhancing the endogenous production of NO to inhibit the proliferation of RCC cells. Since numerous conflicting results about the role of iNOS and NO in cancer have been reported (53), understanding the multifaceted role of NO in cancer is imperative. The biochemistry, type of tumor, and the spatial and temporal effects of its production need to be more carefully studied in association with IFN $\gamma$. Our findings can have multiple implications in RCC treatment not only by eliminating tumor cells and inhibiting angiogenesis, but more importantly by identifying the sets of patients with RCC that will benefit from IFN $\gamma$ treatment.

\section{Acknowledgements}

This work was supported by grant LEQSF(20-04-07)-RD-A-20 from the Louisiana Board of Regents and startup funds from the Stanley S. Scott Cancer Center at LSUHSC-NO. The authors greatly thank Dr. Robert H. Wiltrout who kindly provided us with the cell lines, Ms. Jonna Ellis for editing the manuscript, and Dr. Jeff Hobden for his critical review.

\section{Conflict of Interest}

All authors have declared that no conflicts of interest exist and agree with the contents of the manu- script for publication.

\section{References}

1. Siegel R, Ward E, Brawley O, Jemal A. Cancer statistics, 2011: the impact of eliminating socioeconomic and racial disparities on premature cancer deaths. CA Cancer J Clin 2011 Jul;61(4):212-36.

2. Staehler M, Rohrmann K, Bachmann A, Zaak D, Stief CG, Siebels M. Therapeutic approaches in metastatic renal cell carcinoma. BJU Int 2005 Jun;95(8):1153-61.

3. Bleumer I, Oosterwijk E, De MP, Mulders PF. Immunotherapy for renal cell carcinoma. Eur Urol 2003 Jul;44(1):65-75.

4. Atkins MB, Regan M, McDermott D. Update on the role of interleukin 2 and other cytokines in the treatment of patients with stage IV renal carcinoma. Clin Cancer Res 2004 Sep 15;10(18 Pt 2):6342S-6S.

5. McDermott DF, Regan MM, Clark JI, Flaherty LE, Weiss GR, Logan TF, Kirkwood JM, Gordon MS, Sosman JA, Ernstoff MS, Tretter CP, Urba WJ, et al. Randomized phase III trial of high-dose interleukin-2 versus subcutaneous interleukin-2 and interferon in patients with metastatic renal cell carcinoma. J Clin Oncol 2005 Jan 1;23(1):133-41.

6. Atkins MB, Bukowski RM, Escudier BJ, Figlin RA, Hudes GH, Kaelin WG, Jr., Linehan WM, McDermott DF, Mier JW, Pedrosa I, Rini BI, Signoretti $S$, et al. Innovations and challenges in renal cancer: summary statement from the Third Cambridge Conference. Cancer 2009 May 15;115(10 Suppl):2247-51.

7. Ko JS, Zea AH, Rini BI, Ireland JL, Elson P, Cohen P, Golshayan A, Rayman PA, Wood L, Garcia J, Dreicer R, Bukowski R, et al. Sunitinib mediates reversal of myeloid-derived suppressor cell accumulation in renal cell carcinoma patients. Clin Cancer Res 2009 Mar 15;15(6):2148-57.

8. De Mulder PH. Targeted therapy in metastatic renal cell carcinoma. Ann Oncol 2007 Jul;18 Suppl 9:ix98-102.

9. Sosman JA, Puzanov I, Atkins MB. Opportunities and obstacles to combination targeted therapy in renal cell cancer. Clin Cancer Res 2007 Jan 15;13(2 Pt 2):764s-9s.

10. Morris SM, Jr. Recent advances in arginine metabolism: roles and regulation of the arginases. Br J Pharmacol 2009 Jul;157(6):922-30.

11. Munder M. Arginase: an emerging key player in the mammalian immune system. Br J Pharmacol 2009 Oct;158(3):638-51.

12. Bronte V, Zanovello P. Regulation of immune responses by L-arginine metabolism. Nat Rev Immunol 2005 Aug;5(8):641-54.

13. Viola A, Bronte V. Metabolic mechanisms of cancer-induced inhibition of immune responses. Semin Cancer Biol 2007 Aug;17(4):309-16.

14. Peranzoni E, Marigo I, Dolcetti L, Ugel S, Sonda N, Taschin E, Mantelli B, Bronte V, Zanovello P. Role of arginine metabolism in immunity and immunopathology. Immunobiology 2007;212(9-10):795-812.

15. Wu G, Morris SM, Jr. Arginine metabolism: nitric oxide and beyond. Biochem J 1998 Nov 15;336 ( Pt 1):1-17.

16. Li H, Meininger CJ, Kelly KA, Hawker JR, Jr., Morris SM, Jr., Wu G. Activities of arginase I and II are limiting for endothelial cell proliferation. Am J Physiol Regul Integr Comp Physiol 2002 Jan;282(1):R64-R69.

17. Buga GM, Wei LH, Bauer PM, Fukuto JM, Ignarro LJ. NG-hydroxy-L-arginine and nitric oxide inhibit Caco-2 tumor cell proliferation by distinct mechanisms. Am J Physiol 1998 Oct;275(4 Pt 2):R1256-R1264.

18. Zea AH, Rodriguez PC, Culotta KS, Hernandez CP, DeSalvo J, Ochoa JB, Park HJ, Zabaleta J, Ochoa AC. L-Arginine modulates CD3zeta expression and $\mathrm{T}$ cell function in activated human T lymphocytes. Cell Immunol 2004 Nov;232(1-2):21-31.

19. Munder M, Eichmann K, Moran JM, Centeno F, Soler G, Modolell M. Th1/Th2-regulated expression of arginase isoforms in murine macrophages and dendritic cells. J Immunol 1999 Oct 1;163(7):3771-7.

20. Finke JH, Rini B, Ireland J, Rayman P, Richmond A, Golshayan A, Wood L, Elson P, Garcia J, Dreicer R, Bukowski R. Sunitinib reverses type-1 immune suppression and decreases T-regulatory cells in renal cell carcinoma patients. Clin Cancer Res 2008 Oct 15;14(20):6674-82.

21. Tatsumi T, Kierstead LS, Ranieri E, Gesualdo L, Schena FP, Finke JH, Bukowski RM, Mueller-Berghaus J, Kirkwood JM, Kwok WW, Storkus WJ. Disease-associated bias in T helper type 1 (Th1)/Th2 CD4(+) T cell responses against MAGE-6 in HLA-DRB10401(+) patients with renal cell carcinoma or melanoma. J Exp Med 2002 Sep 2;196(5):619-28.

22. Onishi T, Ohishi Y, Imagawa K, Ohmoto Y, Murata K. An assessment of the immunological environment based on intratumoral cytokine production in renal cell carcinoma. BJU Int 1999 Mar;83(4):488-92.

23. Tate DJ, Jr., Vonderhaar DJ, Caldas YA, Metoyer T, Patterson JR, Aviles $\mathrm{DH}$, Zea AH. Effect of arginase II on L-arginine depletion and cell growth in murine cell lines of renal cell carcinoma. J Hematol Oncol 2008;1:14. 
24. Dutcher JP, Fine JP, Krigel RL, Murphy BA, Schaefer PL, Ernstoff MS, Loehrer PJ. Stratification by risk factors predicts survival on the active treatment arm in a randomized phase II study of interferon-gamma plus/minus interferon-alpha in advanced renal cell carcinoma (E6890). Med Oncol 2003;20(3):271-81.

25. Kirkwood JM, Bryant J, Schiller JH, Oken MM, Borden EC, Whiteside TL. Immunomodulatory function of interferon-gamma in patients with metastatic melanoma: results of a phase II-B trial in subjects with metastatic melanoma, ECOG study E 4987. Eastern Cooperative Oncology Group. J Immunother 1997 Mar;20(2):146-57.

26. Berner V, Liu H, Zhou Q, Alderson KL, Sun K, Weiss JM, Back TC, Longo DL, Blazar BR, Wiltrout RH, Welniak LA, Redelman D, et al. IFN-gamma mediates CD4+ T-cell loss and impairs secondary antitumor responses after successful initial immunotherapy. Nat Med 2007 Mar;13(3):354-60.

27. Hillman GG, Younes E, Visscher D, Hamzavi F, Kim S, Lam JS, Montecillo EJ, Ali E, Pontes JE, Puri RK, Haas GP. Inhibition of murine renal carcinoma pulmonary metastases by systemic administration of interferon gamma: mechanism of action and potential for combination with interleukin 4. Clin Cancer Res 1997 Oct;3(10):1799-806.

28. Gruys ME, Back TC, Subleski J, Wiltrout TA, Lee JK, Schmidt L, Watanabe M, Stanyon R, Ward JM, Wigginton JM, Wiltrout RH. Induction of transplantable mouse renal cell cancers by streptozotocin: in vivo growth, metastases, and angiogenic phenotype. Cancer Res 2001 Aug 15;61(16):6255-63.

29. Zea AH, Culotta KS, Ali J, Mason C, Park HJ, Zabaleta J, Garcia LF, Ochoa AC. Decreased expression of CD3zeta and nuclear transcription factor kappa B in patients with pulmonary tuberculosis: potential mechanisms and reversibility with treatment. J Infect Dis 2006 Nov 15;194(10):1385-93.

30. Cory AH, Owen TC, Barltrop JA, Cory JG. Use of an aqueous soluble tetrazolium/formazan assay for cell growth assays in culture. Cancer Commun 1991 Jul;3(7):207-12.

31. Zea AH, Rodriguez PC, Atkins MB, Hernandez C, Signoretti S, Zabaleta J, McDermott D, Quiceno D, Youmans A, O'Neill A, Mier J, Ochoa AC. Arginase-producing myeloid suppressor cells in renal cell carcinoma patients: a mechanism of tumor evasion. Cancer Res $2005 \mathrm{Apr}$ 15;65(8):3044-8

32. Haas GP, Hillman GG. Update on the Role of Immunotherapy in the Management of Kidney Cancer. Cancer Control 1996 Nov;3(6):536-41.

33. Hillman GG, Younes E, Visscher D, Hamzavi F, Kim S, Lam JS, Montecillo EJ, Ali E, Pontes JE, Puri RK, Haas GP. Inhibition of murine renal carcinoma pulmonary metastases by systemic administration of interferon gamma: mechanism of action and potential for combination with interleukin 4. Clin Cancer Res 1997 Oct;3(10):1799-806.

34. Negrier S, Escudier B, Lasset C, Douillard JY, Savary J, Chevreau C, Ravaud A, Mercatello A, Peny J, Mousseau M, Philip T, Tursz T. Recombinant human interleukin-2, recombinant human interferon alfa-2a, or both in metastatic renal-cell carcinoma. Groupe Francais d'Immunotherapie. N Engl J Med 1998 Apr 30;338(18):1272-8.

35. Motzer RJ, Bacik J, Murphy BA, Russo P, Mazumdar M. Interferon-alfa as a comparative treatment for clinical trials of new therapies against advanced renal cell carcinoma. J Clin Oncol 2002 Jan 1;20(1):289-96.

36. Rosenberg SA, Lotze MT, Yang JC, Linehan WM, Seipp C, Calabro S, Karp SE, Sherry RM, Steinberg S, White DE. Combination therapy with interleukin-2 and alpha-interferon for the treatment of patients with advanced cancer. J Clin Oncol 1989 Dec;7(12):1863-74.

37. Spencer WF, Linehan WM, Walther MM, Haas GP, Lotze MT, Topalian SL, Yang JC, Merino MJ, Lange JR, Pockaj BA, . Immunotherapy with interleukin-2 and alpha-interferon in patients with metastatic renal cell cancer with in situ primary cancers: a pilot study. J Urol 1992 Jan;147(1):24-30.

38. Ellerhorst JA, Kilbourn RG, Amato RJ, Zukiwski AA, Jones E, Logothetis CJ. Phase II trial of low dose gamma-interferon in metastatic renal cell carcinoma. J Urol 1994 Sep;152(3):841-5.

39. Ernstoff MS, Nair S, Bahnson RR, Miketic LM, Banner B, Gooding W, Day R, Whiteside T, Hakala T, Kirkwood JM. A phase IA trial of sequential administration recombinant DNA-produced interferons: combination recombinant interferon gamma and recombinant interferon alfa in patients with metastatic renal cell carcinoma. J Clin Oncol 1990 Oct;8(10):1637-49.

40. Ikeda H, Old LJ, Schreiber RD. The roles of IFN gamma in protection against tumor development and cancer immunoediting. Cytokine Growth Factor Rev 2002 Apr;13(2):95-109.

41. Angiolillo AL, Sgadari C, Taub DD, Liao F, Farber JM, Maheshwari S, Kleinman HK, Reaman GH, Tosato G. Human interferon-inducible pro- tein 10 is a potent inhibitor of angiogenesis in vivo. J Exp Med $1995 \mathrm{Jul}$ 1;182(1):155-62.

42. Ignarro LJ. The unique role of nitric oxide as a signaling molecule in the cardiovascular system. Ital Heart J 2000 Sep;1 Suppl 3:S28-S29.

43. Li H, Meininger CJ, Hawker JR, Jr., Haynes TE, Kepka-Lenhart D, Mistry SK, Morris SM, Jr., Wu G. Regulatory role of arginase I and II in nitric oxide, polyamine, and proline syntheses in endothelial cells. Am J Physiol Endocrinol Metab 2001 Jan;280(1):E75-E82.

44. Wang WW, Jenkinson CP, Griscavage JM, Kern RM, Arabolos NS, Byrns RE, Cederbaum SD, Ignarro LJ. Co-induction of arginase and nitric oxide synthase in murine macrophages activated by lipopolysaccharide. Biochem Biophys Res Commun 1995 May 25;210(3):1009-16.

45. Gotoh T, Mori M. Arginase II downregulates nitric oxide (NO) production and prevents NO-mediated apoptosis in murine macrophage-derived RAW 264.7 cells. J Cell Biol 1999 Feb 8;144(3):427-34.

46. Sousa MS, Latini FR, Monteiro HP, Cerutti JM. Arginase 2 and nitric oxide synthase: Pathways associated with the pathogenesis of thyroid tumors. Free Radic Biol Med 2010 Sep 15;49(6):997-1007.

47. Hussain SP, Trivers GE, Hofseth LJ, He P, Shaikh I, Mechanic LE, Doja S, Jiang W, Subleski J, Shorts L, Haines D, Laubach VE, et al. Nitric oxide, a mediator of inflammation, suppresses tumorigenesis. Cancer Res 2004 Oct 1;64(19):6849-53.

48. Rodriguez PC, Quiceno DG, Ochoa AC. L-arginine availability regulates T-lymphocyte cell-cycle progression. Blood 2007 Feb 15;109(4):1568-73.

49. Singh R, Pervin S, Karimi A, Cederbaum S, Chaudhuri G. Arginase activity in human breast cancer cell lines: N(omega)-hydroxy-L-arginine selectively inhibits cell proliferation and induces apoptosis in MDA-MB-468 cells. Cancer Res 2000 Jun 15;60(12):3305-12.

50. Korkola JE, Blaveri E, DeVries S, Moore DH, Hwang ES, Chen YY, Estep $\mathrm{AL}$, Chew KL, Jensen RH, Waldman FM. Identification of a robust gene signature that predicts breast cancer outcome in independent data sets. BMC Cancer 2007;7:61.

51. Brinckmann A, Axer S, Jakschies D, Dallmann I, Grosse J, Patzelt T, Bernier T, Emmendoerffer A, Atzpodien J. Interferon-alpha resistance in renal carcinoma cells is associated with defective induction of signal transducer and activator of transcription 1 which can be restored by a supernatant of phorbol 12-myristate 13-acetate stimulated peripheral blood mononuclear cells. Br J Cancer 2002 Feb 1;86(3):449-55.

52. Shang D, Liu Y, Ito N, Kamoto T, Ogawa O. Defective Jak-Stat activation in renal cell carcinoma is associated with interferon-alpha resistance. Cancer Sci 2007 Aug;98(8):1259-64.

53. Fukumura D, Kashiwagi S, Jain RK. The role of nitric oxide in tumour progression. Nat Rev Cancer 2006 Jul;6(7):521-34. 